Tohoku J. Exper. Med., 1963, 81, 138-142

\title{
Effect of Vitamin A on the Uptake by Rats of Sulfur Administered as Sulfate or Methionine
}

\author{
By
}

\author{
Tatsuo Koyanagi and Takatoshi Tatebayashi \\ Laboratory of Nutrition, Faculty of Agriculture, \\ Tohoku University, Sendai
}

(Received for publication, October 5, 1963)

\begin{abstract}
It was observed that in 24 hours following the injection of the labeled sulfate more than twice the amount of sulfur was found in intestine, stomach, liver and eyes of vitamin A supplemented rat, as compared with that in those tissues of the deficient one.

When $S^{35}$-methionine was administered, in contrast to the case of $\mathbf{S}^{35}$-sulfate, $S^{35}$ concentration in tissues of control rat was significantly less than in those of vitamin A-deficient animal.
\end{abstract}

Vitamin A deficiency shows its first manifestation in a disruption and atrophy of all those epithelial tissues that function in mucus secretion: in the respiratory, intestinal, and urinary tracts and in the genital system. A decrease in the number and activity of mucus-secreting cells of the gastro-intestinal tract occurs ${ }^{1)}$. Since esterified sulfate represents an important part of the mucopolysaccharide molecule, a number of investigations have considered the effect of vitamin A deficiency on sulfate incorporation into cartilage. Dziewiatkowsky ${ }^{2}$ ) isolated chondroitin sulfate, the principal substance, apart from collagen, of cartilage matrix, after injection of labeled sulfate into vitamin A-deficient and normal rats. The level of labeled sulfate was higher in the normal rats than in the deficient ones. Using a homogenate of rat colon, Wolf and Varandani ${ }^{3)}$ observed lower mucopolysaccharide synthesis in vitamin A deficiency, as demonstrated by the uptake of labeled sulfate. Recent results of Morett et al. ${ }^{4)}$ seem to indicate that vitamin A participates in the activation reaction of sulfate.

Koyanagi et al. found that the deficiency of vitamin A decreased the cystine content of skin of rats ${ }^{5}$ and that of hair of children ${ }^{6}$ ) and suggested the dependence of sulfur amino acid metabolism on vitamin A.

In the present report the level of labeled sulfate taken in the various tissues

小楖達男，馆林孝利 
after administration of labeled-sulfate or methionine to vitamin A-deficient and normal rats has been studied.

\section{EXPERIMENTAL}

Male rats of Wister strain were divided into 2 groups and fed the rations outlined in Table I. The basal ration (Group 1) contained powdered milled rice, defatted soybean meal, cottonseed oil, salts ${ }^{7}$, choline-Cl and water soluble vitamin mixture ${ }^{8}$ ). Per $100 \mathrm{~g}$ of the diet $100 \mathrm{i} . \mathrm{u}$. of vitamin $\mathrm{D}$ (calciferol) and $1 \mathrm{mg}$ of $a$-tocopherol acetate in drops of cottonseed oil were supplemented. Group 2 received the same ration but in addition one drop of vitamin A palmitate 2000 i.u./ml of cottonseed oil was given per os every other day. The diet was made into a paste by heating with $140 \mathrm{ml}$ water per $100 \mathrm{~g}$ of the diet.

Table I. Composition of Basal Diet

\begin{tabular}{l|c}
\multicolumn{1}{c|}{ Constituent } & per cent \\
\hline Washed milled rice powder & 60 \\
Defatted soybean meal (solvent) & 25 \\
Cottonseed oil & 8 \\
Salts & 5 \\
Water soluble vitamin mixture & 1 \\
Choline-Cl* & 1 \\
* Choline-Cl 20\% mixture in starch
\end{tabular}

Rats were housed in individual cages with a screen bottom, and pair fed while water was given ad lib. Particular care was taken to use the animals when they had not yet reached too severe a degree of deficiency. The animals were deemed "deficient" at a time when weight loss had just set in after having been fed the deficient diet.

In the first experiment, when their weight had just begun to level off $1.7 \times$ $10^{6} \mathrm{cpm}$ of $\mathrm{S}^{35}$-sulfate in $0.1 \mathrm{ml}$ water was given by intraperitoneal injection. Animals from each group were sacrificed 24 hours later.

Measurement of radioactivity: The animals were killed by decapitation, about $0.5 \mathrm{~g}$ of tissues was dissected for analysis, washed with $0.9 \%$ saline and digested with Pirie's reagent ${ }^{9}$. The sulfate was precipitated as Benzidine sulfate $^{10}$. The precipitate of benzidine sulfate was collected on a filter paper disk and radioactivity of each sample was determined with $2 \pi$ Windowless gas-flow counter. All values for radioactivity were corrected for self absorption.

In the second experiment the procedures and the analysis were the same as outlined above except that $1.4 \times 10^{6} \mathrm{cpm}$ of $\mathrm{S}^{35}$-methionine was given per os instead of sulfate. $\mathrm{S}^{35}$-methionine was prepared by the method of Niklas ${ }^{11)}$ using torula utilis. It was cultured in a medium containing labeled sulfate. $\mathrm{S}^{35}$-methionine thus produced in yeast was isolated by paper chromatography after hydrolysis. 
Measurement of vitamin $\mathrm{A}$ in liver: About $2 \mathrm{~g}$ of liver was taken from each rat and determined by the procedure described by Ames ${ }^{12)}$.

\section{RESULTS}

Exp. 1. Effect of vitamin A deficiency on the distribution of $\mathrm{S}^{35}$ in tissues of rats injected $\mathbb{S}^{35}$-sulfate.

In Table II are given the average concentrations of $S^{35}$ found in the various tissues of rat that received basal diet or vitamin A supplemented diet. It can be seen that in 24 hours following the injection of the isotope it was more distributed in the tissue of the rats fed the vitamin A supplemented diet than in those of rat fed the basal diet. On examination of the content of $\mathrm{S}^{35}$ in tissues, such as intestine, stomach, liver and eye more than twice the amount of sulfur was concentrated in vitamin $A$ supplemented rat than in the deficient one.

Exp. 2. Effect of vitamin A deficiency on the distribution of $\mathbf{S}^{35}$ in tissues of rats

TABLE II. Distribution of Labeled Sulfur 24 Hours after Administration of $\mathrm{S}^{35} \mathrm{O}_{4}$

\begin{tabular}{l|c|c|c}
\hline \multicolumn{1}{c|}{ Tissues } & $\begin{array}{r}\text { Vitamin A-deficient } \\
\mathrm{cpm} / \mathrm{g}\end{array}$ & $\begin{array}{r}\text { Control } \\
\mathrm{cpm} / \mathrm{g}\end{array}$ & Control/Deficient \\
\hline Small intestine & 7137 & 18394 & 2.6 \\
Eye & 1281 & 3221 & 2.5 \\
Lung & 2126 & 4708 & 2.2 \\
Stomach & 5528 & 11552 & 2.1 \\
Cartilage ensiform & 3843 & 6794 & 1.8 \\
Kidney & 3153 & 5213 & 1.7 \\
Liver & 1883 & 3100 & 1.6 \\
Spleen & 3383 & 5255 & 1.6 \\
Body weight (g) & 129 & 214 &
\end{tabular}

TABLE III. Distribution of Labeled Sulfur 24 Hours after Administration of $\mathrm{S}^{35}$-Methionine

\begin{tabular}{l|c|c|c}
\hline \multicolumn{1}{c|}{ Tissues } & $\begin{array}{c}\text { Vitamin A-deficient } \\
\text { cpm/g }\end{array}$ & $\begin{array}{c}\text { Control } \\
\text { cpm/g }\end{array}$ & Deficient/Control \\
\hline Liver & 22160 & 4931 & 4.5 \\
Small intestine & 18744 & 5550 & 3.4 \\
Stomach & 9615 & 3606 & 2.7 \\
Kidney & 4664 & 2405 & 1.9 \\
Spleen & 4000 & 2196 & 1.8 \\
Lung & 3418 & 2842 & 1.2 \\
Femur & 2916 & & \\
Adrenal & 1410 & 1840 & 0.8 \\
Eye & 1136 & 1030 & 1.1 \\
Brain & 690 & 492 & 1.4 \\
Body weight (g) & 164 & 247 &
\end{tabular}


fed $\mathbf{S}^{35}$-methionine.

Results of analysis are shown in Table III. When $\mathrm{S}^{35}$-methionine was administered, in contrast to the case of $\mathrm{S}^{35}$-sulfate, $\mathrm{S}^{35}$ concentration in tissues of control rat was significantly low, as compared with that in the deficient animal.

\section{DISCUSSION}

The results of experiments with $\mathrm{S}^{35}$-sulfate are in agreement with those reported by Dziewiatkowsky ${ }^{2}$. He showed that the metabolism of chondroitin sulfate in the skelton is under the influence of vitamin $A$, for the specific activity of the $S^{35}$ in the chondroitin sulfate samples isolated from the skelton is affected by the administration of this vitamin. He also stated that the rate at which sulfate sulfur is incorporated into the sulfomucopolysaccharide of the skin of vitamin A-deficient rat is slightly lower than the rate of incorporation observed in normal rat.

The results of the present experiment showed that the vitamin A influences the metabolism of $\mathrm{S}^{35}$-sulfate remarkably in tissues such as intestine, stomach, lung, eye and liver. It is interesting to note that the named organs are kuown to be highly susceptible to the effect of vitamin A deficiency.

Contrary to our expectation the amount of sulfur of $S^{35}$-methionine was concentrated significantly less in the tissues of normal rat as compared with that in those of the deficient rat.

It is not known whether the increased concentration of $S^{35}$ in the tissues of the vitamin $\mathrm{A}$-deficient rat administered $\mathrm{S}^{35}$-methionine is due to the retarded metabolic rate or increased uptake of $\mathrm{S}^{35}$-methionine by their tissues. In this connection it is notewothy that Prosky ${ }^{13)}$ has reported that $\mathrm{S}^{35}$ uptake of the rat administered $\mathrm{S}^{35}$-methionine was larger in rats fed methionine-deficient ration than in rats fed the normal ration. So the increased concentration of $\mathrm{S}^{35}$ in the tissues of the deficient rat in present experiment might be due to the condition of tissues comparable to that of tissues of rats fed the methonine-deficient ration. It must be emphasized, however, that the authors dealt only with the tissues obtained 24 hours after injection of labeled methionine.

The rate of hourly change of various $\mathrm{S}^{35}$ compounds derived from $\mathrm{S}^{35}$-methionine in the tissues of vitamin A-deficient and normal rats is under investigation.

\section{References}

1) Manville, I.A., Science, 1937, 85, 44.

2) Dziewiatkowsky, D.D., J. exp. Med., 1954, $100,10$.

3) Wolf, G. \& Varandani, P.T., Biochim. biophys. Acta, 1960, 43, 501.

4) Moretti, A. \& Wolf, G., Biochim. biophys. Acta, 1961, 53, 263.

5) Koyanagi, T. \& Odagiri, S., Nature, 1960, 186, 809.

6) Koyanagi, T. \& Takanohashi, T., Nature, 1961, 192, 457. 
7) Phillips, P.H. \& Hart, E.B., J. biol. Chem., 1935, 109, 657.

8) Wolf, G., Lane, M.D. \& Johnson, B.C., J. biol. Chem., 1957, 225, 997.

9) Pirie, N.W., Biochem. J., 1932, 26, 2044.

10) Fiske, C.H., J. biol. Chem., 1921, 47, 59.

II) Nikals, A., Hoppe-Seyler's Z. physiol. Chem., 1955, 301, 194.

12) Ames, S.R., Analytic. Chem., 1954, 26, 1378.

I3) Prosky, L., J. Nutr., 1962, 78, 419. 